\title{
DIFERENÇAS DE RENDIMENTO E FLUXO ENTRE OS TIPOS DE OFERTA DO ENSINO MÉDIO: UMA ANÁLISE EXPLORATÓRIA
}

\author{
Robson dos Santos ${ }^{\mathrm{I}}$
}

Gustavo Henrique Moraes ${ }^{\mathrm{II}}$

Ana Elizabeth M. de Albuquerque ${ }^{\mathrm{III}}$

http://dx.doi.org/10.24109/9786558010074.ceppe.v3a3

\section{RESUMO}

O ensino médio no Brasil apresenta, ao longo de sua história, uma diversidade de formas de oferta. Tendo isso em conta, o estudo analisou, de forma exploratória, as variações nas taxas de rendimento e fluxo, considerando os diferentes tipos de oferta do ensino médio. Por meio de estatísticas descritivas, verificou se a repetência, o

\footnotetext{
I Doutor e mestre em Sociologia pela Universidade Estadual de Campinas (Unicamp) e em Política Social pela Universidade de Brasília (UnB). Possui especialização em estatística aplicada. Tem experiência como sociólogo em órgãos da administração pública federal como docente de sociologia no ensino médio e na educação superior. Atualmente, trabalha como pesquisador-tecnologista em Informações e Avaliações Educacionais no Instituto Nacional de Estudos e Pesquisas Educacionais Anísio Teixeira (Inep). Áreas de interesse e atuação atuais: sociologia da educação, educação de populações do campo, educação de jovens e adultos, indicadores educacionais e métodos quantitativos em ciências sociais.

II Pesquisador de carreira do Instituto Nacional de Estudos e Pesquisas Educacionais Anísio Teixeira (Inep/MEC). De formação multidisciplinar - doutor em Educação pela Universidade de Brasília (UnB) e mestre em Educação Científica e Tecnológica pela Universidade Federal de Santa Catarina (UFSC) e engenheiro em Eletrônica e Telecomunicações pela Universidade Tecnológica Federal do Paraná (UTFPR). Privilegia as abordagens que buscam conciliar as esferas qualitativas e quantitativas da pesquisa, respaldadas por abordagens históricas e estatísticas. Atualmente, ocupa o cargo de coordenador geral de Instrumentos e Medidas Educacionais da Diretoria de Estudos Educacionais (Dired) do Inep, sendo responsável pelos estudos de monitoramento do Plano Nacional de Educação (PNE).

III Doutora em Educação e mestre em Gestão da Educação pela Universidade de Brasília (UnB). Pesquisadora do Instituto Nacional de Estudos e Pesquisas Educacionais Anísio Teixeira (Inep). Professora de Educação Profissional e Tecnológica. Atua principalmente nos seguintes campos: políticas públicas e gestão da educação; educação profissional e tecnológica.
} 
abandono e a evasão, fenômenos que afetam a universalização da educação básica no Brasil, apresentam tendências distintas quando se leva em conta que a oferta do ensino médio ocorre de forma propedêutica, por meio de cursos técnicos integrados ou pelo normal/magistério. Os resultados apontam para a permanência dos fenômenos (reprovação, abandono e repetência) na etapa de ensino médio, mas com diferenças relevantes. Ressalte-se que os cursos técnicos integrados apresentaram, em média, menores valores de repetência, abandono e evasão frente aos registrados nos demais tipos de oferta.

Palavras-chave: abandono; ensino médio; evasão; repetência.

\section{INTRODUÇÃO}

As formas de inserção do ensino médio no sistema educacional brasileiro acumulam um histórico de divergências quanto às suas finalidades e, em paralelo, de reformas visando torná-lo contemporâneo às necessidades e projetos sociais e políticos de cada período. Por um lado, essa etapa de ensino responderia aos objetivos, como registra o art. $2^{\circ}$ da Lei de Diretrizes e Bases da Educação Nacional (LDB), de garantir o "pleno desenvolvimento do educando, seu preparo para o exercício da cidadania e sua qualificação para o trabalho" (Brasil, 1996). Por outro, o ensino médio comportaria múltiplos desígnios sociais e econômicos: posição intermediária entre o ensino fundamental e o superior? Etapa que antecede o ingresso no mercado de trabalho? Estratégia de profissionalização e qualificação para atividades produtivas? Meio para o aprofundamento dos conhecimentos e a preparação para o prosseguimento nos estudos?

Para Nosella (2015, p. 20), "o ensino médio é a fase escolar estratégica do sistema escolar e do processo de democratização e modernização de uma nação”. Já na interpretação de Castro et al. (2018, p. 4), "o ensino médio é o período de transição entre a educação fundamental e a educação superior ou a vida profissional”. De certo modo, o artigo 35 da LDB também engloba esse conjunto de sentidos, ao registrar que:

O ensino médio, etapa final da educação básica, com duração mínima de três anos, terá como finalidades:

I - a consolidação e o aprofundamento dos conhecimentos adquiridos no ensino fundamental, possibilitando o prosseguimento de estudos;

II - a preparação básica para o trabalho e a cidadania do educando, para continuar aprendendo, de modo a ser capaz de se adaptar com flexibilidade a novas condições de ocupação ou aperfeiçoamento posteriores;

III - o aprimoramento do educando como pessoa humana, incluindo a formação ética e o desenvolvimento da autonomia intelectual e do pensamento crítico; 

IV - a compreensão dos fundamentos científico-tecnológicos dos processos produtivos, relacionando a teoria com a prática, no ensino de cada disciplina (Brasil, 1996).

As diversas finalidades atribuídas ao ensino médio e os esforços para a sua melhoria se defrontam, todavia, com desigualdades entre os grupos no que se refere ao acesso e nas possibilidades de integralização. Essa preocupação se confirma em diferentes metas do Plano Nacional de Educação (PNE): a Meta 3, por exemplo, tem como objetivo que "a taxa líquida de matrículas no ensino médio [seja elevada] para 85\%”; a Meta 7 propõe que o Índice de Desenvolvimento da Educação (Ideb) para a referida etapa atinja 5,2, até 2021; a Meta 8 estabelece que a escolaridade média da população de 18 a 29 anos seja elevada a 12 anos de estudo, o que equivale atualmente à conclusão do ensino médio; e a Meta 11, que sejam triplicadas "as matrículas da educação profissional técnica de nível médio" (Brasil, 2014). O alcance desses alvos requer, inescapavelmente, a garantia do acesso à escola, mas isso, per si, é insuficiente, dada a necessidade de que ocorra o aprendizado, a permanência e a conclusão. É sobre essas duas últimas dimensões que o ensino médio é analisado neste trabalho.

De início, é preciso retificar, por ser equivocada, a concepção de que o Brasil conta ou contava com apenas uma possibilidade de formação/itinerário no ensino médio. O fato é que a etapa já se caracterizava, bem antes de seu último ciclo de reformas, em 2017, por uma diversidade de tipos de oferta, distando, assim, de um modelo unitário e homogêneo para todos os estudantes que nele ingressavam.

Basta lembrar que, além da oferta de ensino médio propedêutico, existem cursos profissionalizantes, cuja orientação é tipicamente vocacional e voltada para o mundo do trabalho, sem que a formação deixe de ser contemplada. Esses cursos estão categorizados como educação profissional técnica de nível médio ${ }^{1}$ e são ofertados de forma articulada, podendo ainda ser compostos de maneiras distintas. Sobre isso, os termos dos art. 36-B e art. 36-C da LDB definem, mais especificamente, duas alternativas de articulação à educação profissional técnica de nível médio: a primeira é a integrada, na mesma instituição de ensino, com matrícula única para cada aluno; a outra é a concomitante, com matrículas distintas para cada curso, na mesma ou em outra instituição de ensino, mediante projeto pedagógico unificado (Brasil. MEC. CNE. CEB, 2012). ${ }^{2}$

Tais tipos de oferta podem realizar-se na idade própria, no ensino médio regular, ou na modalidade de Educação de Jovens e Adultos (EJA). A Tabela 1 apresenta a diversidade existente nos tipos de oferta, bem como a evolução das matrículas no ensino médio, no período de 2013 a 2018.

Decreto $\mathrm{n}^{0} 5.154 / 2004$

2 Há também a oferta de curso técnico subsequente, para quem concluiu o ensino médio, que o configura como uma oferta pós-média, mas que foge ao escopo deste estudo, no qual trataremos apenas da oferta integrada ao ensino médio. 
TABELA 1

MATRÍCULAS NO ENSINO MÉdIO E NA EDUCAÇÃO PROFISSIONAL TÉCNICA DE NÍVEL MÉdIO BRASIL - 2013-2018

\begin{tabular}{|l|l|l|c|c|c|c|c|c|}
\hline & Ensino & $\begin{array}{c}\text { Ensino } \\
\text { Mnédio } \\
\text { Médio } \\
\text { Propedêutico } \\
\text { Normal/ } \\
\text { Magistério }\end{array}$ & $\begin{array}{c}\text { Técnico } \\
\text { Integrado } \\
\text { (Ensino } \\
\text { Médio } \\
\text { Integrado) }\end{array}$ & & Total* & $\begin{array}{c}\text { Curso } \\
\text { Técnico } \\
\text { Concomitante }\end{array}$ & $\begin{array}{c}\text { Ensino } \\
\text { Médio } \\
\text { EJA de } \\
\text { ensino } \\
\text { regular }\end{array}$ & $\begin{array}{c}\text { Curso } \\
\text { Técnico } \\
\text { (Ensino } \\
\text { Médio) } \\
\text { Integrada } \\
\text { à EJA }\end{array}$ \\
\hline 2013 & 7.855 .385 & 120.246 & 338.417 & 8.314 .048 & 310.218 & 1.284 .048 & 41.269 & 1.635 .535 \\
\hline 2014 & 7.833 .168 & 101.224 & 366.988 & 8.301 .380 & 328.740 & 1.266 .171 & 42.875 & 1.637 .786 \\
\hline 2015 & 7.590 .465 & 93.919 & 391.766 & 8.076 .150 & 278.212 & 1.270 .198 & 38.228 & 1.586 .638 \\
\hline 2016 & 7.601 .197 & 102.833 & 429.010 & 8.133 .040 & 329.033 & 1.342 .137 & 32.710 & 1.703 .880 \\
\hline 2017 & 7.376 .065 & 94.793 & 459.526 & 7.930 .384 & 328.073 & 1.383 .046 & 35.043 & 1.746 .162 \\
\hline 2018 & 7.125 .365 & 78.773 & 505.791 & 7.709 .929 & 354.346 & 1.395 .658 & 35.145 & 1.785 .149 \\
\hline
\end{tabular}

Fonte: Elaboração própria com base em dados do Brasil. Inep (2014; 2015; 2016; 2017; 2018b).

* Inclui matrículas do Ensino Médio Propedêutico, do Ensino Médio Normal/Magistério e do Curso Técnico Integrado (Ensino Médio Integrado).

* * Inclui Curso Técnico Concomitante, Ensino Médio EJA de ensino regular, Curso Técnico (Ensino Médio) Integrado à EJA.

Os distintos tipos de oferta de ensino médio se materializam em uma heterogeneidade de instituições ofertantes, pertencentes a diferentes dependências administrativas e redes de ensino, formas de organização do trabalho pedagógico e do currículo, etc. Essa variabilidade produz uma miríade de condições de oferta, ${ }^{3}$ podendo se relacionar com o desempenho e a permanência dos estudantes.

Tendo em conta a diversidade dos tipos de oferta do ensino médio, o estudo comparou, em caráter exploratório e por meio de análises estatísticas descritivas, as taxas de rendimento e de fluxo entre o ensino médio regular propedêutico e a educação profissional técnica de nível médio entre os anos de 2013 e de 2017. ${ }^{4}$ Desse modo, objetiva-se compreender as relações entre o tipo de oferta e as variações nas taxas de reprovação, abandono e evasão.

Para contextualizar as análises, o estudo conta com uma parte inicial que caracteriza as desigualdades de acesso e de conclusão da educação básica, buscando situar o objeto de investigação. Na sequência, descreve as diferenças nas taxas de rendimento e de fluxo no ensino médio, considerando os dados relativos a três formas de organização: o ensino médio propedêutico, o curso técnico integrado e o normal

\footnotetext{
A diversidade da oferta pode ser verificada ainda nas 185 denominações de cursos técnicos, listados pelo Catálogo Nacional de Cursos Técnicos e agrupados conforme suas características científicas e tecnológicas em 12 eixos.

4 A análise sobre a taxas de rendimento e fluxo se estenderam até o ano de 2017, pois, à época da finalização do estudo, eram os mais atuais disponíveis. Os dados descritivos sobre o quantitativo de matrículas puderam contemplar o ano de 2018.
} 
magistério, os dois últimos integrantes da educação profissional técnica de nível médio. Por fim, realiza uma síntese das principais conclusões.

\section{DESIGUALDADES NA CONCLUSÃO E A OFERTA DO ENSINO MÉDIO}

As possibilidades de conclusão do ensino médio se distribuem desigualmente e, quando se concretizam, constituem um fator que (re)produz assimetrias sociais importantes, tanto do ponto de vista das possibilidades de ampliação do repertório de conhecimentos científicos, tecnológicos e culturais, quanto da inserção produtiva e da continuidade do processo de formação intelectual e profissional dos indivíduos.

No que se refere à renda, para ficar apenas em um exemplo, os retornos relacionados à posse do ensino médio também constituem um fator a se considerar; por isso as

políticas que melhorem a qualidade do sistema educacional público nos níveis fundamental e médio parecem ser relevantes, visto que elevam o retorno salarial da escolaridade, além de prepararem os jovens das classes menos favorecidas para entrarem na universidade (Nakabashi; Assahide, 2017, p. 171).

Apesar da relevância associada à posse do ensino médio, um breve panorama feito a partir da Pnad Contínua revela que a conclusão da referida etapa ainda constitui um desafio a ser vencido no campo educacional brasileiro. Em 2018, praticamente a metade da população brasileira com idade igual ou superior a 19 anos não contava com o médio completo, embora seja essa a idade em que se espera que todos que o acessaram já o tenham concluído ${ }^{5}$ (Gráfico 1). Em 2012, por exemplo, 57,5\% da população com idade superior a 19 anos não possuía o ensino médio e, em 2018, o valor era de 50,1\%, ainda elevado, apesar da redução verificada.

\footnotetext{
5 A expectativa ideal é que a pessoa conclua o ensino médio até os 17 anos de idade. De modo a ter um intervalo que permita incluir o período ideal para a conclusão da educação básica e contemplar possíveis atrasos, analisamos a conclusão do ensino médio entre a população de 19 anos ou mais. Nesse caso, cumpre lembrar que estão sendo considerados todos os indivíduos com 19 anos ou mais de idade, independentemente de ainda estarem frequentando a escola ou não. Nesse caso, foram agrupados aqueles que detinham o ensino médio completo, o superior incompleto ou superior completo, como possuindo a educação básica completa. De modo alternativo, os que não possuíam instrução, mas tinham o fundamental incompleto ou completo ou o médio incompleto, compunham o grupo sem a educação básica completa e integram a categoria.
} 


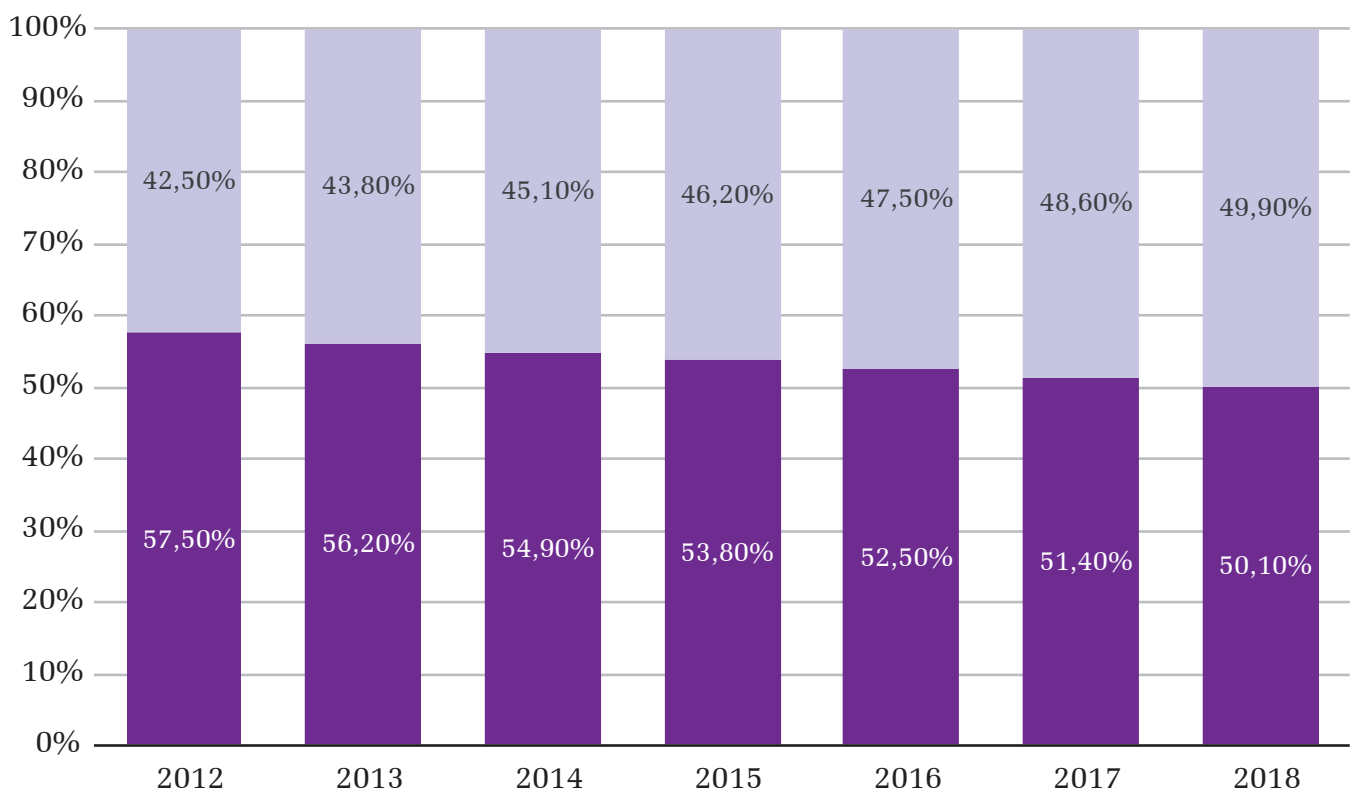

- Não possui o ensino médio completo $\backsim$ Possui o ensino médio completo

GRÁFICO 1

\section{PERCENTUAL DA POPULAÇÃO BRASILEIRA DE 19 ANOS OU MAIS DE IDADE, SEGUNDO A} CONCLUSÃO DO ENSINO MÉDIO - BRASIL - 2012-2018

Fonte: Elaboração própria com base em dados da Pnad Contínua/IBGE.

$90,0 \%$

$85,0 \%$

$\begin{array}{llllll}84,9 \% & 84,1 \% & & & \\ 80,0 \% & 82,6 \% & 81,4 \% & 80,5 \% & 79,2 \% & 78,9 \% \\ 75,0 \% & & & & 79 \%\end{array}$

$70,0 \%$

$65,0 \%$

$66,9 \%$

$65,9 \%$

$64,8 \%$

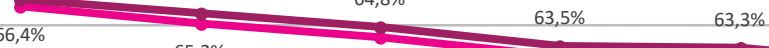

$63,5 \% \quad 63,3 \% \quad 62,1 \%$

$65,2 \% \quad 64,1 \%$

$60,0 \%$

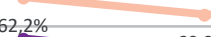

$60,8 \%$

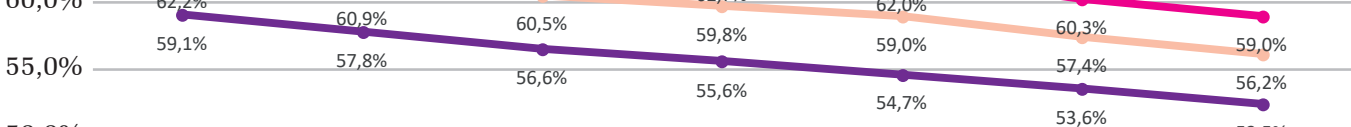

$50,0 \%$

$53,6 \%$

$52,5 \%$

$45,0 \%$

$40,0 \%$

2012

2013

2014

2015

2016

2017

2018

Brasil Campo Negros $\simeq$ Norte $\sim$ Nordeste

\section{GRÁFICO 2}

\section{PERCENTUAIS DA POPULAÇÃO BRASILEIRA DE 19 ANOS OU MAIS DE IDADE QUE NÃO} FREQUENTA A ESCOLA E NÃO POSSUI A EDUCAÇÃO BÁSICA (2012-2018)

Fonte: Elaboração própria com base em dados da Pnad Contínua/IBGE. 
Ao selecionar apenas a população com 19 anos ou mais de idade que não frequentava mais a escola ${ }^{6}$ isto é, que não estava acessando formalmente os níveis de escolarização, o percentual daqueles que não possuíam o ensino médio completo era ainda mais elevado, sobretudo ao se levar em conta algumas desagregações. Entre a população residente no campo, 78,9\% não tinham o ensino médio completo. Entre os residentes na região Nordeste, esse valor chegava a 60,8\% e entre os negros ${ }^{7}$ a $59 \%$. (Gráfico 2).

Desses dados se depreende uma situação conhecida: um elevado contingente de pessoas que não possuem o ensino médio completo, mesmo tendo a idade para tal. Além disso, os dados também ajudam a recordar que a conclusão do ensino médio constitui um processo desigualmente distribuído na população brasileira. Estão na região Nordeste, notadamente no campo e entre a população negra, os maiores percentuais de pessoas sem o ensino médio completo aos 19 anos.

De modo complementar, podemos contrapor o número total de estudantes matriculados no ensino médio, o que pode incluir todas as faixas etárias, e o total da população de 15 a 17 anos de idade. Em 2018, essa população era de 9.752 .471 pessoas, o que pode ser tomado como o número potencial de matrículas no ensino médio, enquanto o total de matrículas era de 7.709 .929 (Gráfico 3).

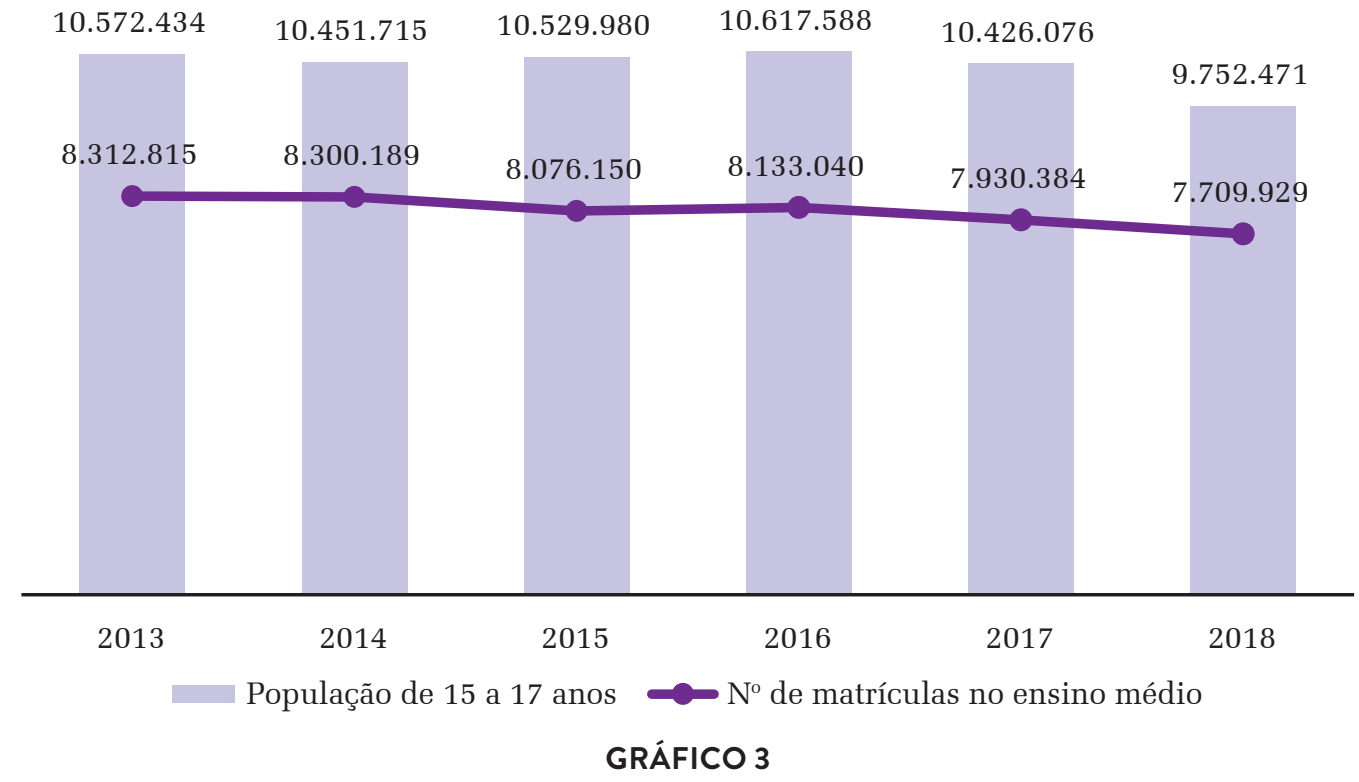

POPULAÇÃO DE 15 A 17 ANOS DE IDADE E NÚMERO DE MATRÍCULAS NO ENSINO MÉDIO BRASIL - 2013-2018

Fonte: Elaboração própria com base em dados da Pnad Contínua/IBGE e do Censo Escolar/ Inep.

${ }_{6}$ Independentemente de nível e/ou etapa.

7 Como registra o artigo art. $1^{\circ}$, parágrafo único, inciso IV da Lei $\mathrm{n}^{\circ} 12.288$, de julho de 2010, que institui o Estatuto da Igualdade Racial, na categoria está incluso "o conjunto de pessoas que se autodeclaram pretas e pardas, conforme o quesito cor ou raça usado pela Fundação Instituto Brasileiro de Geografia e Estatística (IBGE), ou que adotam autodefinição análoga”. 
A diferença entre a totalidade da população-alvo do ensino médio e o número totalidade das matrículas na etapa pode ser explicada pelas situações de evasão, atraso, abandono do sistema escolar ${ }^{8}$ e pela contabilização do público que nunca o frequentou. $\mathrm{O}$ fato é que muitos jovens brasileiros não conseguem nem mesmo acessar o ensino médio, abandonando a escola na etapa anterior, ao final do ensino fundamental e, entre os que o acessam, os níveis de evasão e abandono ainda são preocupantes.

Em estudo recente, Simões (2019) observa que a maioria dos estudantes de 19 anos entrou na escola na idade certa, mas, ao longo de seu processo de escolarização, muitos ficaram retidos ou desistiram, de forma que apenas $64,2 \%$ alcançaram o último ano do ensino médio, em 2017. Grosso modo, é como se de cada 100 estudantes que ingressaram no ensino fundamental na idade correta, aos 6 anos, mais de 35 não chegaram ao $3^{\circ}$ ano do ensino médio na idade prevista, aos 19 anos. Ao compararmos a situação por quintis de renda, percebe-se, de um lado, que, entre os mais pobres, o percentual de conclusão cai para 51\% e, por outro, entre os mais ricos, $85,8 \%$ chegaram ao terceiro ano do ensino médio (Figura 1).

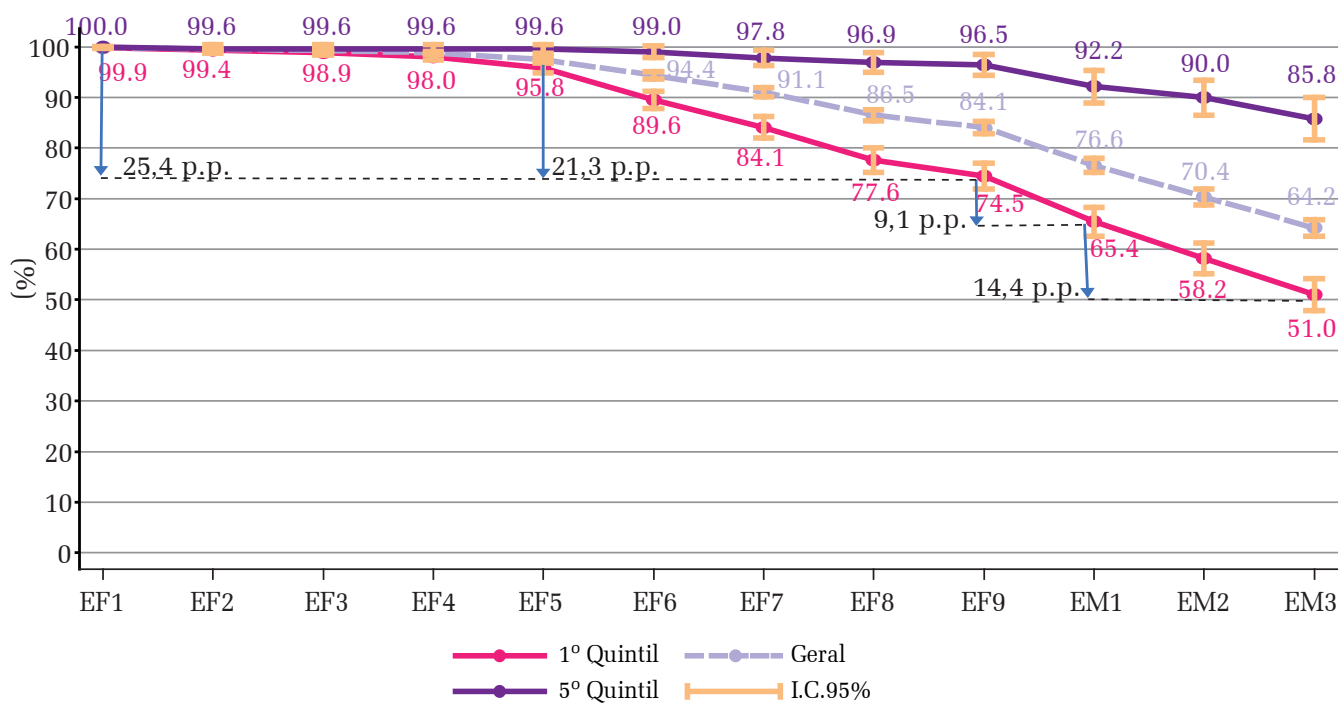

FIGURA 1

PERCENTUAL DA POPULAÇÃO DE 19 ANOS DE IDADE QUE NÃO FREQUENTA, MAS ALCANÇOU (COM APROVAÇÃO) OS ANOS ESCOLARES DA EDUCAÇÃO BÁSICA GERAL, $1^{\circ} \mathrm{E} 5^{\circ}$ QUINTIS DE RENDA DOMICILIAR PER CAPITA - BRASIL - 2017

Fonte: Simões (2019).

A Figura 1 mostra que as desigualdades no fluxo escolar dos estudantes começam nos anos finais do ensino fundamental e se agravam no ensino médio.

\footnotetext{
8 Em um cenário ideal, a diferença seria pequena. É fato que um contingente de jovens pode haver falecido entre os anos e outro concluído ou migrado para a EJA. Todavia, esses fenômenos não explicam a discrepância entre a totalidade da população-alvo do ensino médio e a totalidade das matrículas na etapa.
} 
Ao longo do processo de escolarização, os estudantes podem abandonar o curso, ser reprovados ou se evadir, o que compromete a aderência ideal entre a idade e a série/ ano. ${ }^{9}$ Essa situação repercute em perdas para os indivíduos (em termos de interações sociais, ganhos econômicos e vivências culturais) e para os sistemas de ensino (que são submetidos a custos adicionais, dispêndio de recursos, etc.).

Sem os recursos escolares, a maioria desses jovens e adultos, certamente, se depara com dificuldades adicionais para a inserção ocupacional, o que pode confluir em um quadro no qual eles não trabalham e não estudam, ou, em outras palavras, não acumulam anos de estudo nem auferem retornos salariais pela escolarização obtida, dado não possuírem a educação básica completa. Ressalta-se, nesse sentido, a existência de um percentual elevado de jovens entre 18 e 29 anos de idade (20,8\%, em 2018) que não frequentam a escola, não têm a educação básica completa e se encontram desocupados (Gráfico 4).

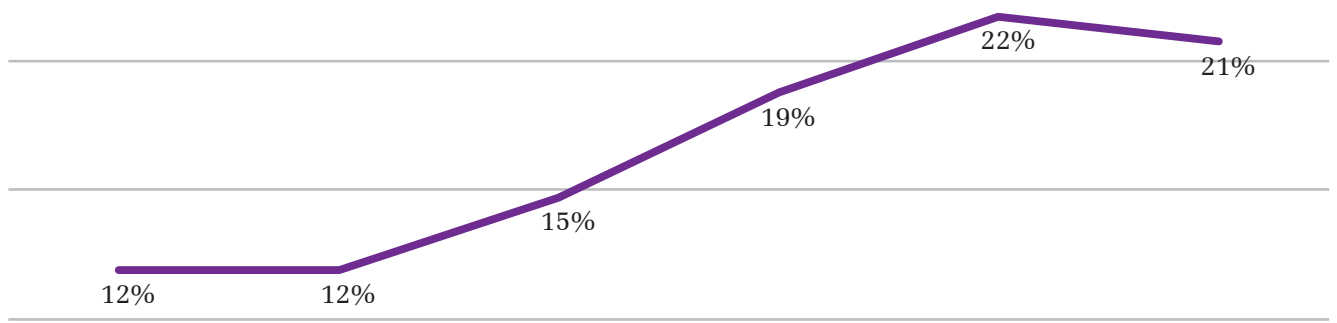

\section{\begin{tabular}{llllll}
\hline 2013 & 2014 & 2015 & 2016 & 2017 & 2018
\end{tabular} GRÁFICO 4 \\ PERCENTUAL DA POPULAÇÃO BRASILEIRA DE 18 A 29 ANOS QUE NÃO FREQUENTA A ESCOLA, NÃO POSSUI A EDUCAÇÃO BÁSICA E NÃO ESTÁ OCUPADA (2013-2018)}

Fonte: Elaboração própria com base em dados da Pnad Contínua/IBGE.

Esse conjunto de dados demonstra que a elevação do ensino médio à categoria de etapa obrigatória convive com uma tensão em torno de sua universalização, que possui relações diretas com as taxas de repetência, abandono e evasão que o caracterizam. Além disso, nota-se que subsistem desigualdades entre os grupos, tornando a ampliação do acesso ao ensino médio um desafio prioritário no conjunto de políticas educacionais. Como reconheceu o texto da Base Nacional Curricular

9 Cumpre lembrar que a adequação entre idade e ano de escolarização estabelecida pela legislação constitui um modelo ideal a ser perseguido pelas políticas educacionais. 
Comum, o ensino médio "representa um gargalo na garantia do direito à educação" (Brasil. MEC, 2018, p. 461).

Até aqui a contextualização buscou disponibilizar informações sobre os "incluídos" e os "excluídos" do sistema de ensino, daí a relevância dos dados demográficos, que permitem uma caracterização dos que estão fora da escola. De modo mais particular, é preciso apresentar algumas informações sobre a distribuição das matrículas no ensino médio por tipo de oferta, considerando agora apenas a situação dos que possuem vínculo com o sistema de ensino, isto é, os "incluídos".

A aproximação inicial à questão pode ser obtida por meio da comparação transversal entre o quantitativo de matrículas no $1^{\circ}$ e no $3^{\circ}$ ano. Como exemplo, tome-se o ano de 2018: no $1^{\circ}$ ano/série do ensino médio propedêutico, eram computadas 2.725.870 matrículas, enquanto no $3^{\circ}$ ano/série o número era de 2.041.927, isto é, uma diferença de 683.943 , ou $25 \%$ a menos. No caso do curso técnico integrado, o $1^{\circ}$ ano contava com 178.444 matrículas, enquanto no terceiro o número era de 119.015, o que representava uma redução de 59.429 matrículas, ou 33,3\% a menos (Gráfico 5).

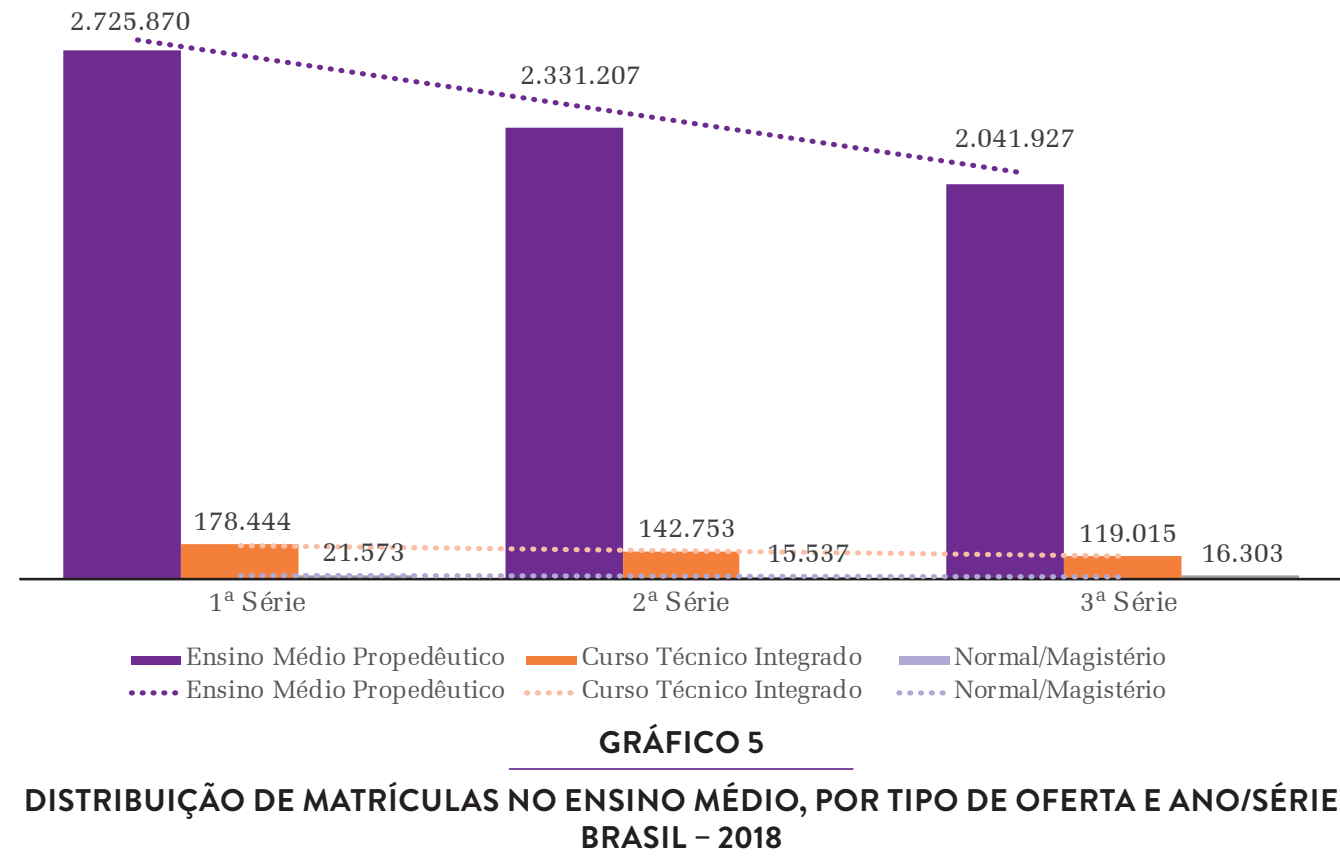

Fonte: Elaboração própria com base em dados do Censo Escolar/Inep. 
Como dito, trata-se de um registro estático, mas que sugere uma redução do número total de matrículas a cada ano, dado que, em um cenário ideal, ${ }^{10}$ o quantitativo encontrado em cada ano seria muito similar.

Pode-se considerar também o número de matrículas nos primeiros anos em 2016 (curso técnico integrado, propedêutico e normal/magistério) e o número de matrículas no terceiro ano, em 2018. Nesse caso, a expectativa é que o número de matrículas no $3^{\circ}$ ano/série (em 2018), seja muito aproximado ao registrado no $1^{\circ}$ ano/série (em 2016). Essa pressuposição faz sentido porque, em um sistema ideal, o contingente daqueles que ingressam no ano $t$ seria muito próximo ao que se verifica no ano $t+1$ e $t+2$, visto que os ingressantes no sistema seguiriam uma trajetória regular e integralizariam o ensino médio em três anos. No caso em questão, em 2016, existiam 2.986 .788 matrículas no primeiro ano do ensino médio e, em 2018, eram 2.041.927 matrículas no terceiro ano do ensino médio, uma diferença de -944.861 matrículas (Tabela 2).

TABELA 2

\section{DISTRIBUIÇÃO DAS MATRÍCULAS NO ENSINO MÉDIO ( $1^{\circ}$ E $3^{\circ}$ ANO), POR TIPO DE OFERTA} BRASIL - 2016/2018

\begin{tabular}{|l|c|c|c|c|}
\multicolumn{1}{|c|}{ Etapa/modalidade } & $\begin{array}{c}\mathbf{2 0 1 6} \\
\left(\mathbf{1}^{\mathbf{0}} \mathbf{a n o}\right)\end{array}$ & $\begin{array}{c}\mathbf{2 0 1 8} \\
\left(\mathbf{3}^{\mathbf{0}} \mathbf{A n o}\right)\end{array}$ & $\begin{array}{c}\text { Diferença } \\
\mathbf{2 0 1 8 - 2 0 1 6}\end{array}$ & \% \\
\hline Ensino médio propedêutico & 2.986 .788 & 2.041 .927 & -944.861 & $-31,6$ \\
\hline Curso técnico integrado & 167.324 & 119.015 & -48.309 & 28,9 \\
\hline Normal/Magistério & 22.128 & 16.303 & -5.825 & $-26,3$ \\
\hline
\end{tabular}

Fonte: Elaboração própria com base em dados do Censo Escolar/Inep.

A consideração dos dados relativos às matrículas aponta para uma tendência de perdas no sistema ao longo dos anos, de modo que um número consistente daqueles que ingressam no primeiro ano não segue até o final do ensino médio sem que os fenômenos da repetência, abandono e evasão ocorram nos diferentes tipos de oferta.

Para entender o fenômeno com mais robustez, é preciso recorrer a acompanhamentos que expressem as trajetórias dos estudantes e suas transições ao longo dos anos. Essas informações permitem apreender o rendimento dos estudantes ao final do ano, bem como sua situação de transição entre os anos escolares. Nesse sentido, a seção seguinte analisa as taxas de rendimento e de transição no ensino médio, tendo em conta uma análise comparativa entre os tipos de oferta, o que permitirá compreender as diferenças que existem entre ensino médio propedêutico, curso técnico integrado e normal/magistério.

\footnotetext{
${ }^{10}$ A aderência ideal entre ano e idade consiste na relação idade/série: $1^{\circ}$ ano EF - 6 anos; $2^{\circ}$ ano EF - 7 anos; $3^{\circ}$ ano EF - 8 anos; ... $3^{\circ}$ ano EM - 17 anos. Trata-se de uma trajetória regular do estudante no sistema de ensino em que a transição de séries de acordo com a idade do estudante ocorre sem repetência ou evasão.
} 


\section{AS TAXAS DE RENDIMENTO E DE TRANSIÇÃO}

A oferta do ensino médio por meio de distintos tipos (curso técnico integrado, propedêutico, magistério) redunda na existência de processos que podem se diferenciar quanto aos resultados obtidos, tanto no que se refere à proficiência quanto no que se refere ao fluxo e rendimento. Para verificar isso, o estudo analisou comparativamente as taxas de rendimento e transição entre os diferentes tipos de oferta do ensino médio. Antes de passar à apresentação e interpretação dos dados, é relevante apresentar algumas definições que caracterizam as respectivas taxas, bem como as agregações que foram realizadas para as análises.

\section{BREVES NOTAS METODOLÓGICAS}

A trajetória do estudante ao longo da educação básica, como foi dito, parte de um processo ideal no qual existiria uma aderência entre a idade do indivíduo e o ano/ série em que ele estaria matriculado. Ao final de cada ano, portanto, o estudante apresenta uma situação de rendimento: aprovação, reprovação ou abandono, que devem somar $100 \%$ e integram as "taxas de rendimento".

Ao iniciar um ano letivo, o estudante pode estar, em relação ao ano anterior, na situação de: promovido, repetente, evadido ou falecido. Essa designação apresenta informações sobre o fluxo dos indivíduos entre os anos escolares, considerando sua situação de matrícula, e caracteriza as "taxas de transição". ${ }^{11}$

Desse modo, as "taxas de rendimento" se referem à situação do estudante dentro de um mesmo ano letivo, considerando sua situação final em dezembro em relação a situação registrada na última quarta-feira do mês de maio; as "taxas de transição", por sua vez, constituem um acompanhamento que registra o que ocorreu entre a situação do estudante ao final do ano e a sua situação de matrícula no ano seguinte.

Essas informações sobre o rendimento e a transição decorrem de informações sobre a matrícula obtidas pelo Censo Escolar da Educação Básica. Os dados relativos ao fluxo/à transição permitem "o desenvolvimento de análises longitudinais e o cálculo de indicadores referentes à trajetória escolar dos alunos, baseados nas informações dos registros escolares e administrativos captados pela pesquisa” (Brasil. Inep, 2017b). As informações tornam viáveis "análises mais detalhadas, permitindo, por exemplo, a desagregação das taxas de transição (promoção, repetência, evasão e migração para EJA) por características dos estudantes e níveis territoriais” (Brasil. Inep, 2017b).

O Quadro 1 apresenta a distribuição das etapas conforme a coleta registrada pelo Censo Escolar no que se refere ao ensino médio, seus tipos de oferta e as respectivas

\footnotetext{
${ }^{11}$ Ver: Nota Técnica nº 8/2017/CGCQTI/Deed.
} 
formas de seriação. O ensino médio propedêutico, a educação profissional técnica de nível médio e a educação de jovens e adultos são formas pelas quais as matrículas se apresentam. Em relação a Educação Profissional e Tecnológica (EPT), cumpre registrar que ela contempla o curso técnico integrado, o normal/magistério, o curso técnico concomitante, o curso técnico subsequente e o curso técnico integrado à EJA.

QUADRO 1

\section{ETAPAS DO ENSINO MÉDIO REGULAR E DA EPT DE NÍVEL MÉDIO, SEGUNDO O CENSO ESCOLAR DA EDUCAÇÃO BÁSICA}

\begin{tabular}{|c|c|}
\hline Classificação & Nome da Etapa \\
\hline \multirow{5}{*}{ Ensino Médio Propedêutico } & Ensino Médio - $1^{\text {a }}$ Série \\
\hline & Ensino Médio - $2^{\text {a }}$ Série \\
\hline & Ensino Médio - $3^{\text {a }}$ Série \\
\hline & Ensino Médio - $4^{\mathrm{a}}$ Série \\
\hline & Ensino Médio - Não Seriada \\
\hline \multirow{12}{*}{$\begin{array}{c}\text { Educação Profissional Técnica } \\
\text { de Nível Médio }\end{array}$} & $\begin{array}{l}\text { Curso Técnico Integrado } \\
\text { (Ensino Médio Integrado) } 1^{\text {a }} \text { Série }\end{array}$ \\
\hline & $\begin{array}{l}\text { Curso Técnico Integrado } \\
\text { (Ensino Médio Integrado) 2a Série }\end{array}$ \\
\hline & $\begin{array}{l}\text { Curso Técnico Integrado } \\
\text { (Ensino Médio Integrado) } 3^{\text {a }} \text { Série }\end{array}$ \\
\hline & $\begin{array}{l}\text { Curso Técnico Integrado } \\
\text { (Ensino Médio Integrado) } 4^{\text {a }} \text { Série }\end{array}$ \\
\hline & $\begin{array}{l}\text { Curso Técnico Integrado } \\
\text { (Ensino Médio Integrado) Não Seriada }\end{array}$ \\
\hline & Ensino Médio - Normal/Magistério $1^{\text {a }}$ Série \\
\hline & Ensino Médio - Normal/Magistério $2^{\text {a }}$ Série \\
\hline & Ensino Médio - Normal/Magistério $3^{\mathrm{a}}$ Série \\
\hline & Ensino Médio - Normal/Magistério $4^{\mathrm{a}}$ Série \\
\hline & Curso Técnico Concomitante \\
\hline & Curso Técnico Subsequente \\
\hline & Curso Técnico Integrado à EJA \\
\hline EJA & Ensino Médio EJA \\
\hline
\end{tabular}

Fonte: Adaptado de Brasil. Inep (2017c).

Ao observar os tipos de oferta expressos no Quadro 1, vale lembrar que os cursos técnicos subsequentes se processam depois da conclusão do ensino médio. É necessário considerar, também, que os cursos da EJA não costumam contemplar uma organização curricular seriada, valendo-se do regime de matrículas por 
disciplina e/ou semestral. Tal fato impede que as metodologias utilizadas pelo Inep para o cálculo das taxas de transição sejam utilizadas para esses tipos de oferta. Assim, neste estudo, debruçamo-nos sobre três tipos específicos de oferta: o ensino médio propedêutico, o curso técnico integrado (ensino médio integrado) e o ensino médio normal/magistério.

Nesse cenário, a investigação realizou algumas agregações visando conduzir as análises sobre rendimento e transição. O Quadro 2 descreve as etapas do ensino médio inclusas em cada uma das três categorias elaboradas. Como a intenção inicial foi realizar uma média agregada das taxas de rendimento e de transição por tipo de oferta, cada uma delas foi sintetizada em uma única categoria, incluindo apenas do $1^{\circ}$ ao $3^{\circ}$ ano/ série da etapa. Desse modo, o código 1 se refere à agregação dos anos/ séries do ensino médio propedêutico; o código 2, ao curso técnico integrado (ensino médio integrado); e o código 3, ao normal/magistério, compreendendo esses dois últimos como tipos de oferta de educação profissional técnica de nível médio, mas que foram tratados de forma separada com a finalidade de uma compreensão mais detalhada de suas diferenças.

QUADRO 2

ETAPAS DO ENSINO MÉDIO REGULAR E DA EPT DE NÍVEL MÉDIO AGREGADAS

\begin{tabular}{|c|c|c|}
\hline $\begin{array}{l}\text { Código } \\
\text { original }\end{array}$ & Nome da Etapa & Código agregado \\
\hline 25 & Ensino Médio - $1^{\text {a }}$ Série & \multirow{3}{*}{$\begin{array}{c}1 \\
\text { Ensino Médio } \\
\text { Propedêutico }\end{array}$} \\
\hline 26 & Ensino Médio - $2^{a}$ Série & \\
\hline 27 & Ensino Médio - $3^{a}$ Série & \\
\hline 30 & $\begin{array}{l}\text { Curso Técnico Integrado (Ensino Médio } \\
\text { Integrado) } 1^{\text {a }} \text { Série }\end{array}$ & \multirow{3}{*}{$\begin{array}{c}2 \\
\text { Curso Técnico } \\
\text { Integrado }\end{array}$} \\
\hline 31 & $\begin{array}{l}\text { Curso Técnico Integrado (Ensino Médio } \\
\text { Integrado) } 2^{\text {a }} \text { Série }\end{array}$ & \\
\hline 32 & $\begin{array}{l}\text { Curso Técnico Integrado (Ensino Médio } \\
\text { Integrado) } 3^{\text {a }} \text { Série }\end{array}$ & \\
\hline 35 & Ensino Médio - Normal/Magistério $1^{\text {a }}$ Série & \multirow{3}{*}{$\begin{array}{c}3 \\
\text { Normal/magistério }\end{array}$} \\
\hline 36 & Ensino Médio - Normal/Magistério $2^{\text {a }}$ Série & \\
\hline 37 & Ensino Médio - Normal/Magistério $3^{\mathrm{a}}$ Série & \\
\hline
\end{tabular}

Fonte: Adaptado de Brasil. Inep (2017c). 


\section{ANÁLISE COMPARATIVA DO RENDIMENTO E DO FLUXO POR TIPOS DE OFERTA NO ENSINO MÉDIO}

O acesso ao ensino médio constitui um processo em crescimento nos últimos anos (Brasil. Inep, 2018c). A etapa, todavia, abriga condições de repetência, abandono e evasão que, articuladas e/ou somadas ao aprendizado, confluem em um cenário de exclusões e assimetrias.

Nesse cenário, busca-se compreender se os tipos de oferta do ensino médio que apresentam variações no que se refere ao aprendizado e às notas em exames e avaliações (Silva Filho; Moraes, 2017) também contemplam variações relativas ao rendimento e ao fluxo.

A análise começa pelas taxas de repetência, que já foram tratadas como “o grande empecilho à universalização da educação básica em nosso país” (Ribeiro, 1991, p. 13) Na série considerada, ocorreu uma pequena redução entre 2013 e 2017. O percentual de estudantes repetentes apresentava valores diferenciados entre os tipos de oferta. Todavia, os percentuais ainda continuam consideráveis, sobretudo no caso do ensino médio propedêutico, que ostentava o percentual mais elevado de jovens em situação de reprovação. Já os cursos técnicos integrados ou os cursos normal/magistério apresentavam valores menores. Em 2017, o percentual era de 7,8\% no magistério, de 8,9\% no curso técnico integrado e de 9,2\% no ensino médio propedêutico (Gráfico 6).

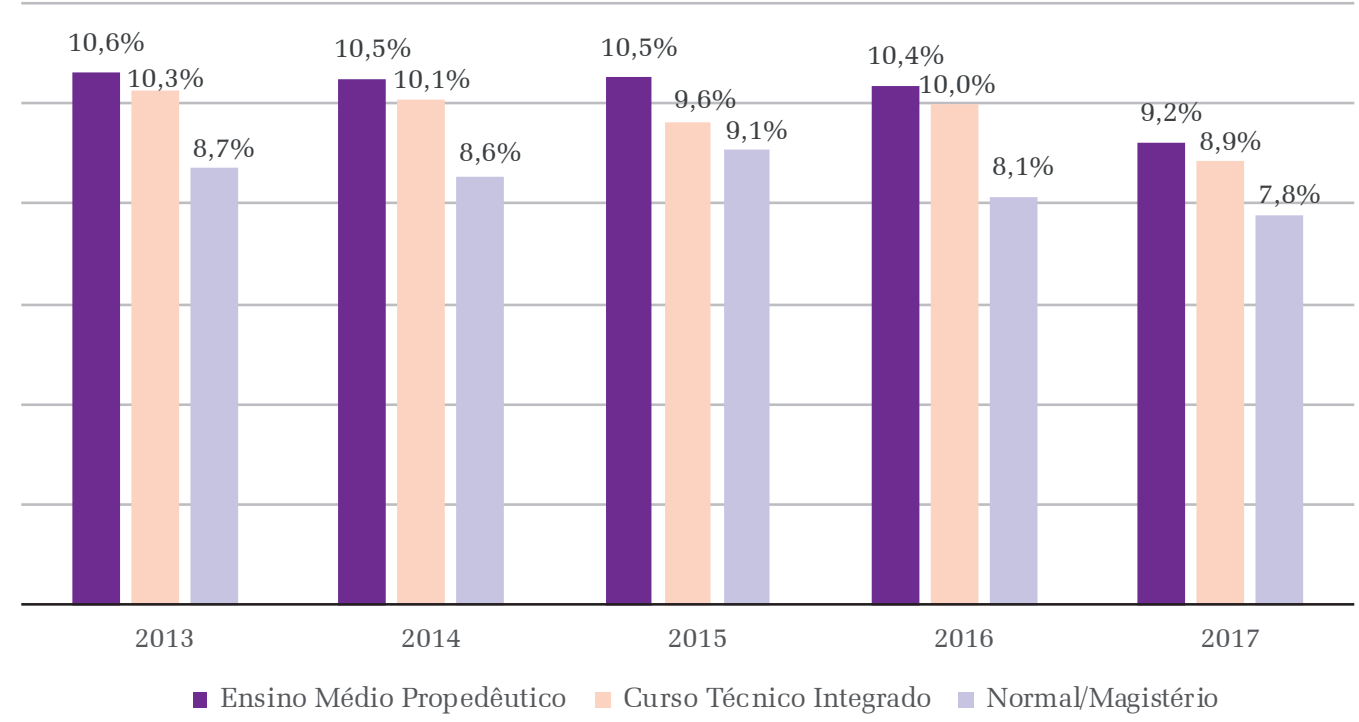

GRÁFICO 6

PERCENTUAL DE REPROVAÇÃO NO ENSINO MÉDIO POR TIPO DE OFERTA - BRASIL 2013-2017

Fonte: Elaboração própria com base em dados do Censo Escolar/ Inep. 
É importante interpretar os dados tendo em conta a diferença consistente entre o número das matrículas em cada tipo de oferta. O ensino médio propedêutico abrigava, em 2018, 92,4\% das matrículas no ensino médio (Tabela 1). De tal modo, o impacto das taxas de reprovação na oferta propedêutico acabou por ser ainda maior, dificultando a melhoria do fluxo e da conclusão da etapa.

Quanto ao abandono escolar, verifica-se em todos os tipos de oferta uma redução dos valores nos últimos anos investigados. A análise comparativa da taxa de abandono registrada para o ensino médio, de modo agregado, contudo, apresenta diferenças entre os tipos de oferta.

O normal/magistério apresentava a maior taxa média de abandono, todavia, representava um quantitativo reduzido de matrículas, menos de 100 mil. Já a comparação entre o ensino médio propedêutico e o curso técnico integrado indicava que o primeiro apresentava, em 2017, uma taxa de abandono média (6,0\%), sendo 2,5 vezes maior que a registrada no curso técnico integrado $(2,3 \%)$.

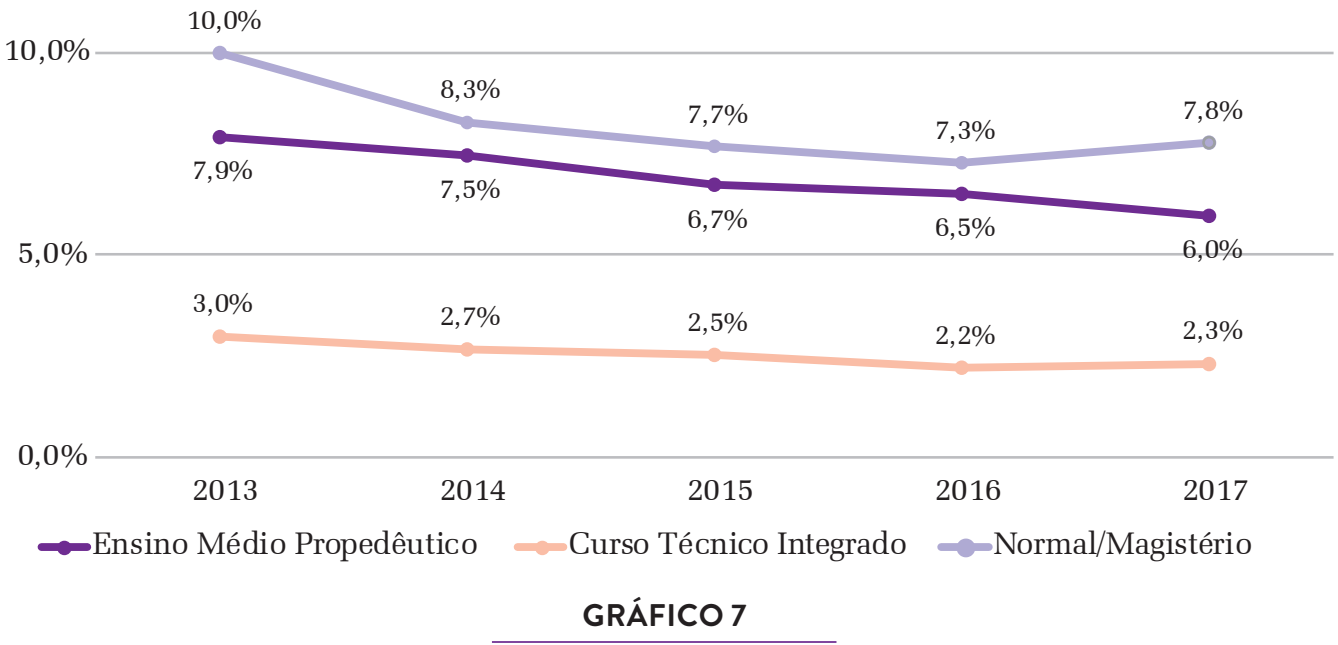

TAXA DE ABANDONO NO ENSINO MÉDIO POR TIPO DE OFERTA - BRASIL - 2013-2017

Fonte: Elaboração própria com base em dados do Censo Escolar/ Inep.

Ao ingressar no ensino médio, o estudante teve seu direito à educação parcialmente atendido, mas ainda não efetivado, visto que apenas com o aprendizado satisfatório e a conclusão do curso a efetivação do direito se integraliza. Nesse sentido, o fenômeno da evasão escolar é complexo, visto que o estudante, nesse caso, acessou o sistema de ensino, mas não o integralizou, na medida em que ele deixou a escola em algum momento. Trata-se, assim, de uma ruptura com importantes repercussões na 
trajetória escolar do aluno, além dos efeitos sobre o sistema de ensino, que assumirá desafios adicionais para uma posterior oferta de educação de jovens e adultos, entre outros.

A comparação das taxas de evasão entre os tipos de oferta mostra que esta constitui um fenômeno mais frequente no magistério/normal, um tipo de oferta em processo de redução acentuada das matrículas, e no ensino médio propedêutico. Em 2017, o percentual médio de evasão era de 4,0\% no curso técnico integrado, de 9,0\% no propedêutico e de 12,5\% no magistério (Gráfico 8). De modo geral, a evasão no curso técnico integrado é 2,5 vezes (350\%) menor que no propedêutico (Gráfico 8).

$20,0 \%$

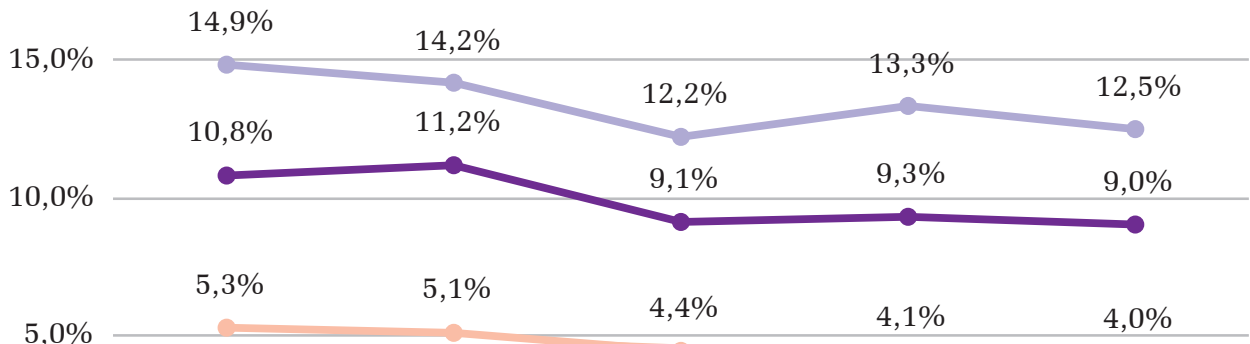

$5,0 \%$

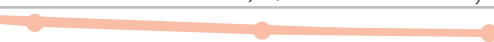

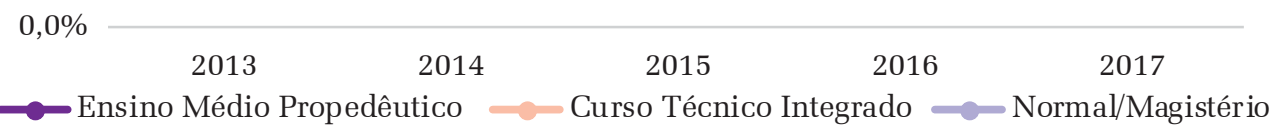

GRÁFICO 8

TAXA DE EVASÃO NO ENSINO MÉDIO POR TIPO DE OFERTA - BRASIL - 2013-2017

Fonte: Elaboração própria com base em dados do Censo Escolar/ Inep.

É importante lembrar que o primeiro ano do ensino médio, em geral, é acompanhado de transições de várias ordens: podem ocorrer alterações de escola, de organização curricular, de professores, de turno, bem como mudanças na trajetória de vida do estudante, como a inserção no mundo do trabalho, os relacionamentos, entre outros aspectos que precisam ser considerados na leitura dos dados, mas que fogem ao escopo deste trabalho abordar. De todo modo, em adição aos dados tomados de forma agregada, é importante analisar o percentual de evasão relativa em cada ano/série, por tipo de oferta, pois, de modo geral, o primeiro ano/série do ensino médio concentra, frequentemente, as maiores taxas de evasão.

Os maiores percentuais registrados, em todos os períodos considerados, foram no primeiro ano do normal/magistério, seguido pelo ensino médio propedêutico. O curso técnico integrado, por sua vez, apresentou um percentual de evadidos menor 
nos três anos/séries do período observado. Nota-se a existência de percentuais mais elevados de evasão no primeiro ano/série, seja qual for o tipo de oferta do ensino médio, mas existem diferenças a ser destacadas. No normal/magistério, o percentual de evadidos na primeira série do curso superava, em 2017, os 15\%; no ensino médio/propedêutico, era maior que $11 \%$. No curso técnico integrado, o percentual era bem menor, sendo de 6,1\%, em 2013, e de 5,1\%, em 2017, metade do que era observado no ensino médio propedêutico (Tabela 3). Em todos as séries consideradas, a evasão no curso técnico integrado era menor que a observada no ensino médio propedêutico.

TABELA 3

PERCENTUAL DE EVASÃO NO ENSINO MÉDIO, POR TIPO DE OFERTA E SÉRIE - BRASIL 2013-2017

\begin{tabular}{|c|c|c|c|c|c|}
\hline ETAPA/ANO & 2013 & 2014 & 2015 & 2016 & 2017 \\
\hline Normal/Magistério - $1^{\text {a }}$ Série & 19,9 & 18,7 & 14,4 & 17,8 & 16,1 \\
\hline Normal/Magistério - $2^{\mathrm{a}}$ Série & 15,4 & 14,7 & 14,5 & 14,0 & 11,4 \\
\hline Normal/Magistério - $3^{\text {a }}$ Série & 8,6 & 8,4 & 7,9 & 8,2 & 9,3 \\
\hline Médio Propedêutico - $1^{\text {a }}$ Série & 12,9 & 12,9 & 10,8 & 11,3 & 11,2 \\
\hline Médio Propedêutico $-2^{\mathrm{a}}$ Série & 11,5 & 12,8 & 9,9 & 10,1 & 9,8 \\
\hline Médio Propedêutico $-3^{\text {a }}$ Série & 6,9 & 6,7 & 5,7 & 5,6 & 5,1 \\
\hline Técnico Integrado - $1^{\text {a }}$ Série & 6,1 & 5,5 & 5,1 & 4,8 & 5,1 \\
\hline Técnico Integrado $-2^{\text {a }}$ Série & 5,3 & 6,1 & 4,8 & 4,6 & 3,8 \\
\hline Técnico Integrado $-3^{\text {a }}$ Série & 3,5 & 3,1 & 2,8 & 2,3 & 2,5 \\
\hline
\end{tabular}

Fonte: Brasil. Inep, 2017b.

Como dito, o estudo possui caráter exploratório, daí o objetivo não foi derivar dos dados até aqui apresentados que o tipo de oferta constitui a variável explicativa principal para fenômenos como a reprovação, o abandono ou a evasão. Ressalta-se que fatores como o tamanho da rede, o nível socioeconômico dos estudantes e a qualidade do ensino não foram considerados na análise.

De modo a complementar o quadro traçado até o momento, é útil examinar como se apresentam as diferenças quando se leva em conta a dependência administrativa em que a oferta ocorre. Para isso, foram analisados os percentuais de reprovação, abandono e evasão, tendo em vista se o curso era federal, estadual, municipal ou privado.

Cabe notar ainda que o abandono escolar no curso propedêutico é alto na esfera federal e pequeno no setor privado. No caso dos outros indicadores, a comparação entre essas duas categorias segue padrão semelhante, com exceção da reprovação, que tende a ser menor no setor privado. No caso do ensino médio propedêutico, o pior cenário é encontrado na rede estadual, que, em 2017, apresentava 11,5\% de reprovados, 6,8\% 
de abandono e uma evasão de 9,9\%. O quadro também negativo foi registrado na rede municipal (Tabela 4).

No caso dos cursos técnicos integrados, a repetência na esfera federal era elevada, o que pode decorrer do nível de exigência dos institutos federais, da transição ensino fundamental/ensino médio de estudantes provenientes de diversas redes e trajetórias escolares, entre outros fatores. Ainda em relação aos cursos técnicos integrados, a evasão na rede privada é alta, destoando das demais esferas e dos percentuais observados em outros tipos de oferta: em 2017, a evasão nos cursos técnicos integrados, na média, era de 3,6\% na rede federal, de 3,5\% na estadual, de $2,2 \%$ na municipal e de $6,1 \%$ na rede privada (Tabela 4).

A interpretação desses dados requer considerar a diferença entre o perfil do estudante que procura um curso técnico integrado privado, possivelmente visando a uma inserção ocupacional mais imediata, ou já trabalhando e buscando elevar sua escolaridade, e o perfil daquele que, por exemplo, realiza no setor privado o ensino médio propedêutico, mais frequentemente voltado a ingressar no ensino superior ou de nível socioeconômico mais elevado. Mas, como dito, essas reflexões exploratórias demandam o uso de dados mais robustos para a caracterização das diferenças no perfil dos estudantes que acessam cada uma das redes de ensino e tipos de oferta.

TABELA 4

RENDIMENTO E FLUXO NO ENSINO MÉDIO, POR TIPO DE OFERTA E DEPENDÊNCIA ADMINISTRATIVA - BRASIL - 2017

\begin{tabular}{|c|c|c|c|c|}
\hline Forma de oferta & Dependência & Reprovado & Abandono & Evadido \\
\hline \multirow{4}{*}{$\begin{array}{l}\text { asino Médio } \\
\text { opedêutico }\end{array}$} & 1 - Federal & $7,5 \%$ & $0,7 \%$ & $3,4 \%$ \\
\hline & 2 - Estadual & $11,5 \%$ & $6,8 \%$ & $9,9 \%$ \\
\hline & 3 - Municipal & $9,9 \%$ & $4,7 \%$ & $8,5 \%$ \\
\hline & 4 - Privada & $3,8 \%$ & $0,3 \%$ & $3,2 \%$ \\
\hline \multirow{4}{*}{$\begin{array}{l}\text { urso Técnico } \\
\text { tegrado }\end{array}$} & 1 - Federal & $11,9 \%$ & $2,1 \%$ & $4,2 \%$ \\
\hline & 2 - Estadual & $6,7 \%$ & $2,6 \%$ & $3,8 \%$ \\
\hline & 3 - Municipal & $6,3 \%$ & $0,7 \%$ & $2,2 \%$ \\
\hline & 4 - Privada & $4,8 \%$ & $1,9 \%$ & $7,2 \%$ \\
\hline \multirow{4}{*}{ ormal/Magistério } & 1 - Federal & & . & \\
\hline & 2 - Estadual & $10,2 \%$ & $7,7 \%$ & $12,0 \%$ \\
\hline & 3 - Municipal & $6,9 \%$ & $16,0 \%$ & $17,8 \%$ \\
\hline & 4 - Privada & $2,2 \%$ & $1,6 \%$ & $14,9 \%$ \\
\hline
\end{tabular}

Fonte: Inep/Taxas de Rendimento e de Transição. 


\section{CONCLUSÕES}

No ano de 2009, a Emenda Constitucional no 59 (CF, art. 208, inciso I) imprimiu como preceito no ordenamento jurídico nacional a "educação básica obrigatória e gratuita dos 4 (quatro) aos 17 (dezessete) anos de idade, assegurada inclusive sua oferta gratuita para todos os que a ela não tiveram acesso na idade própria”, incluindo, portanto, as faixas etárias de 15 a 17 anos ao que era previsto na Constituição Federal de 1988 (7 a 14 anos). Assim, a obrigatoriedade passou a englobar a pré-escola, que deve ser frequentada dos 4 aos 5 anos; o ensino fundamental, dos 6 aos 14 anos; e o ensino médio, idealmente dos 15 aos 17 anos de idade. Isso converteu a busca pela universalização da educação básica em uma finalidade das políticas educacionais.

Contudo, a conclusão do ensino médio é um processo desigualmente distribuído. Metade da população brasileira (50,1\%, em 2018) com idade igual ou superior a 19 anos não possui a educação básica completa, embora seja esta a idade em que se espera que todos tenham concluído o ensino médio, última etapa da educação básica. O elevado percentual de não concluintes ainda é maior entre os residentes no campo, 78,9\%. Entre os residentes na região Nordeste, alcança 60,8\% e entre os negros, 59\%. Há ainda um percentual elevado de jovens entre 18 e 29 anos de idade (20,8\%, em 2018) que não frequentam a escola, não têm a educação básica completa e se encontram desocupadas.

Outrossim, 79,2\% da metade da população brasileira sem ensino médio completo possui ocupação, portanto, o contato com o mundo do trabalho, mas, muitas vezes, de forma precária, porque sem formação e realizando uma transição escola/ mundo do trabalho sem auferir os retornos possíveis de uma formação qualificada.

Importa ressaltar que os processos de saída da escola (abandono e evasão) se iniciam nos anos finais do ensino fundamental, se intensificam no ensino médio e se constituem fenômenos que seguem (re)produzindo barreiras à universalização da educação básica, compreendida como a garantia do acesso à escola, a permanência, o aprendizado e, sobretudo, a conclusão da escolarização obrigatória na idade adequada.

Nesse contexto, daqueles que conseguem se manter na escola, a comparação entre os tipos de oferta de ensino médio mostrou-se relevante para compreender que o modo, a maneira ou a metodologia pela qual se organiza o ensino médio pode ter relação com as taxas de rendimento e de fluxo. A comparação demostrou que os cursos técnicos integrados apresentaram, em média, valores menores de repetência, abandono e evasão escolar em relação ao ensino médio propedêntico e normal magistério.

O primeiro ano/série, independentemente da forma, constitui a etapa que registra os maiores percentuais de abandono e evasão no ensino médio. Mas existem diferenças, visto que, nos cursos técnicos integrados, os percentuais foram bem menores que no ensino médio propedêutico e normal/magistério.

Essas variações sugerem que o rendimento e o fluxo escolar podem se associar com os tipos de oferta do ensino médio, o que precisa ser investigado de forma mais 
detalhada, até mesmo com a inclusão de controles adicionais, de modo a compreender os possíveis efeitos do tipo de organização curricular e a permanência na escola, frente à diversidade do ensino médio brasileiro.

\section{REFERÊNCIAS}

BRASIL. Lei $\mathrm{n}^{\circ}$ 9.394, de 20 de dezembro de 1996. Estabelece as diretrizes e bases da educação nacional. Diário Oficial da União, Brasília, DF, 23 dez. 1996. Seção 1, p. 27833.

BRASIL. Decreto $n^{\circ} 5.154$, de 23 de julho de 2004. Regulamenta o $§ 2^{\circ}$ do art. 36 e os arts. 39 a 41 da Lei $\mathrm{n}^{\circ}$ 9.394, de 20 de dezembro de 1996, que estabelece as diretrizes e bases da educação nacional, e dá outras providências. Diário Oficial da União, Brasília, DF, 26 jul. 2004. Seção 1, p. 18.

BRASIL. Lei $\mathrm{n}^{\circ}$ 11.741, de 16 de julho de 2008. Altera dispositivos da Lei $\mathrm{n}^{\circ}$ 9.394, de 20 de dezembro de 1996, que estabelece as diretrizes e bases da educação nacional, para redimensionar, institucionalizar e integrar as ações da educação profissional técnica de nível médio, da educação de jovens e adultos e da educação profissional e tecnológica. Diário Oficial da União, Brasília, DF, 17 jul. 2008. Seção 1, p. 5.

BRASIL. Lei n ${ }^{\circ}$ 12.288, de 20 de julho de 2010. Institui o Estatuto da Igualdade Racial; altera as Leis nos 7.716, de 5 de janeiro de 1989, 9.029, de 13 de abril de 1995, 7.347, de 24 de julho de 1985, e 10.778, de 24 de novembro de 2003. Diário Oficial da União, Brasília, DF, 21 jul. 2010. Seção 1, p. 1.

BRASIL. Lei $\mathrm{n}^{\circ}$ 13.005, de 25 de junho de 2014. Aprova o Plano Nacional de Educação (PNE) e dá outras providências. Diário Oficial da União, Brasília, DF, 26 jun. 2014. Seção 1, p. 1.

BRASIL. Lei $\mathrm{n}^{\circ}$ 13.415, de 16 de fevereiro de 2017. Altera as Leis $\mathrm{n}^{\text {os }} 9.394$, de 20 de dezembro de 1996, que estabelece as diretrizes e bases da educação nacional, e 11.494, de 20 de junho 2007, que regulamenta o Fundo de Manutenção e Desenvolvimento da Educação Básica e de Valorização dos Profissionais da Educação, a Consolidação das Leis do Trabalho (CLT), aprovada pelo Decreto-Lei no 5.452, de 1o de maio de 1943, e o Decreto-Lei o 236, de 28 de fevereiro de 1967; revoga a Lei no 11.161, de 5 de agosto de 2005; e institui a Política de Fomento à Implementação de Escolas de Ensino Médio em Tempo Integral. Diário Oficial da União, Brasília, DF, 17 fev. 2017. Seção 1, p. 1. 
BRASIL. Instituto Nacional de Estudos e Pesquisas Educacionais Anísio Teixeira (Inep). Microdados: Censo Escolar. Brasília: Inep, [s.d.].

BRASIL. Instituto Nacional de Estudos e Pesquisas Educacionais Anísio Teixeira (Inep). Sinopse estatística da educação básica 2010. Brasília, 2011.

BRASIL. Instituto Nacional de Estudos e Pesquisas Educacionais Anísio Teixeira (Inep). Sinopse estatística da educação básica 2011. Brasília, 2012.

BRASIL. Instituto Nacional de Estudos e Pesquisas Educacionais Anísio Teixeira (Inep). Sinopse estatística da educação básica 2012. Brasília, 2013.

BRASIL. Instituto Nacional de Estudos e Pesquisas Educacionais Anísio Teixeira (Inep). Sinopse estatística da educação básica 2013. Brasília, 2014.

BRASIL. Instituto Nacional de Estudos e Pesquisas Educacionais Anísio Teixeira (Inep). Sinopse estatística da educação básica 2014. Brasília, 2015.

BRASIL. Instituto Nacional de Estudos e Pesquisas Educacionais Anísio Teixeira (Inep). Sinopse estatística da educação básica 2015. Brasília, 2016.

BRASIL. Instituto Nacional de Estudos e Pesquisas Educacionais Anísio Teixeira (Inep). Sinopse estatística da educação básica 2016. Brasília, 2017a.

BRASIL. Instituto Nacional de Estudos e Pesquisas Educacionais Anísio Teixeira (Inep). Nota Técnica no 8/2017 CGCQTI/Deed. Estimativa de fluxo escolar a partir do acompanhamento longitudinal dos registros de aluno do Censo Escolar do período 2007-2016. Brasília, 27 jun. 2017b.

BRASIL. Instituto Nacional de Estudos e Pesquisas Educacionais Anísio Teixeira (Inep). Microdados: Censo Escolar 2017. Brasília: Inep, 2017c. Disponível em: <http://portal.inep.gov.br/microdados >. Acesso em: 12 nov. 2019.

BRASIL. Instituto Nacional de Estudos e Pesquisas Educacionais Anísio Teixeira (Inep). Resumo técnico: resultados do índice de desenvolvimento da educação básica. Brasília, 2018a.

BRASIL. Instituto Nacional de Estudos e Pesquisas Educacionais Anísio Teixeira (Inep). Sinopse estatística da educação básica 2017. Brasília, 2018b.

BRASIL. Instituto Nacional de Estudos e Pesquisas Educacionais Anísio Teixeira (Inep). Relatório do $2^{\circ}$ ciclo de monitoramento das metas do Plano Nacional de Educação - 2018. Brasília, 2018c. 
BRASIL. Ministério da Educação (MEC). Base Nacional Comum Curricular: educação é a base. Brasília: MEC, 2018.

BRASIL. Ministério da Educação (MEC). Conselho Nacional da Educação (CNE). Câmara da Educação Básica (CEB), Resolução n 6, de 20 de setembro de 2012. Define Diretrizes Curriculares Nacionais para a Educação Profissional Técnica de Nível Médio. Diário Oficial da União, Brasília, DF, 21 set. 2012. Seção 1, p. 22.

CASTRO, C. M. et al. A reforma do ensino médio e sua base curricular. 2018. Disponível em: < https://archive.org/details/EnsinoMedioVersao27Jun>. Acesso em: 12 nov. 2019.

CUNHA, C. Ensino médio no Brasil: evolução de ideias, propostas e perspectivas. In: GOMES, C. A.; VASCONCELOS, I. C. O.; COELHO, S. R. S. (Org.). Ensino médio: impasses e dilemas. Brasília: Cidade Gráfica, 2018.

INSTITUTO BRASILEIRO DE GEOGRAFIA E ESTATÍSTICA (IBGE). Pesquisa Nacional por Amostra de Domicílios Contínua: microdados 2012-2018. Rio de Janeiro: IBGE, [s.d.].

NAKABASHI, L.; ASSAHIDE, L. Estimando o retorno da escolaridade dos jovens por classe de renda: 1997-2012. Pesquisa e Planejamento Econômico, Brasília, v. 47, n. 3, p. 137-183, dez. 2017.

NOSELLA, P. Ensino médio: unitário ou multiforme? Revista Brasileira de Educação, Rio de Janeiro, v. 20, n. 60, p. 121-142, mar. 2015.

RIBEIRO, S. C. A pedagogia da repetência. Estudos Avançados. São Paulo, v. 5, n. 12, p. 7-21, ago. 1991.

SILVA FILHO, G. A.; MORAES, G. H. Comparando desempenhos de diferentes tipos de escola de ensino médio: uma aproximação de medida de valor adicionado. Boletim na Medida, Brasília, v. 6, n. 12, ago. 2017.

SIMÕES, A. A. As metas de universalização da educação básica no Plano Nacional de Educação: o desafio do acesso e a evasão dos jovens de famílias de baixa renda no Brasil. Brasília, 2016. (PNE em Movimento, n. 4).

SIMÕES, A. A., 2019. Acesso à educação básica e sua universalização: missão ainda a ser cumprida. Cadernos de Estudos e Pesquisas em Políticas Educacionais. Brasília: Inep, 2018. 
